\title{
Antineoplastic Radiopharmaceutical Agent
}

National Cancer Institute

\section{Source}

National Cancer Institute. Antineoplastic Radiopharmaceutical Agent. NCI Thesaurus.

Code C129819.

Any radiopharmaceutical agent that targets cancer cells and exerts an antineoplastic

effect through radiotoxicity. 